\title{
Cranial Intraosseous Angiolipoma: Case Report and Literature Review
}

\author{
Katherine M Morgan, MD, $P h D^{1}$, Simon Hanft, $M D^{2}$ and Zhenggang Xiong, $M D, P h D^{1^{*}}$ \\ ${ }^{1}$ Department of Pathology and Laboratory Medicine, Robert Wood Johnson Medical School, Rutgers University, USA \\ ${ }^{2}$ Department of Neurosurgery, Robert Wood Johnson Medical School, Rutgers University, USA
}

*Corresponding author: Dr. Zhenggang Xiong, MD, PhD, Department of Pathology and Laboratory Medicine, Robert Wood Johnson Medical School and University Hospital, Rutgers University, 1 Robert Wood Johnson Place, New Brunswick, NJ 08903, USA

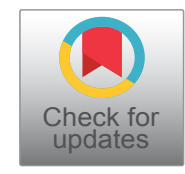

\begin{abstract}
Angiolipomas are slow-growing, soft tissue tumors consisting of mature adipocytes and thin-walled blood vessels. While most Angiolipomas are subcutaneous lesions in the trunk and upper extremities, intraosseous angiolipomas are rare at cranial site. We present the case of a 61-year-old female with an enlarging lesion in the left frontoparietal skull following minor head trauma. Radiography confirmed an expansile, enhancing, spiculated bony lesion in the left frontoparietal calvarium with extension outside the cortex into the soft tissues. She underwent a craniectomy for complete resection of the calvarial mass, which was histologically composed of mature adipocytes and disorganized blood vessels highlighted by an immunophenotype positive for $\mathrm{S} 100$ and CD34, respectively, consistent with a cranial intraosseous angiolipoma. The review of the literature that reported five cases of cranial intraosseous angiolipoma with our case representing the sixth case is discussed.
\end{abstract}

\section{Keywords}

Intraosseous angiolipoma, Calvarium, Cranium, Skull bone, Soft tissue tumor

\section{Introduction}

Angiolipomas are benign tumors composed of mature adipocytes admixed with thin-walled blood vessels. Most are found in the trunk and upper extremities [1]. While angiolipomas are predominantly subcutaneous lesions, intraosseous angiolipomas are very rare tumors that occur most commonly in the rib [2,3] and mandible $[4,5]$. A literature review revealed only five reported cases of cranial intraosseous angiolipomas [6-10]. These lesions can mimic lipomas, angiomas, fibrous dysplasia, meningiomas, or metastases on computed tomography (CT) and magnetic resonance imaging (MRI) and, thus, should be included in the differential diagnosis of an enlarging skull mass $[6,7,9]$. Herein, we describe a rare case of cranial intraosseous angiolipoma and further discuss this entity by reviewing the literature.

\section{Case Report}

\section{Clinical history}

A 61-year-old female with hypertension and arthritis, as well as a history of both squamous cell carcinoma and basal cell carcinoma, was referred to our institute for evaluation of an enlarging palpable left frontoparietal bone lesion. Six months prior to presentation, the patient hit her head on a closet rail and subsequently noted a lump on the left frontoparietal aspect of her scalp. She was then followed up with CT and MRI of the brain with and without contrast, revealing a growing expansile, striated, enhancing lesion in the left frontoparietal cranial bone, which appeared to abut the superior sagittal sinus. The lesion disrupted the inner and outer tables of the cranial bone and indented the extra-axial space of the left frontoparietal region with extension outside of the cortex into the soft tissues. There was no evidence of cerebral parenchymal involvement, except for cerebral compression (Figure 1A, Figure 1B, Figure 1C, Figure 1D and Figure 1E). The differential diagnosis including metastatic disease or an atypical hemangioma was radiologically considered. Subsequently, a total body bone scan was also performed and only revealed 

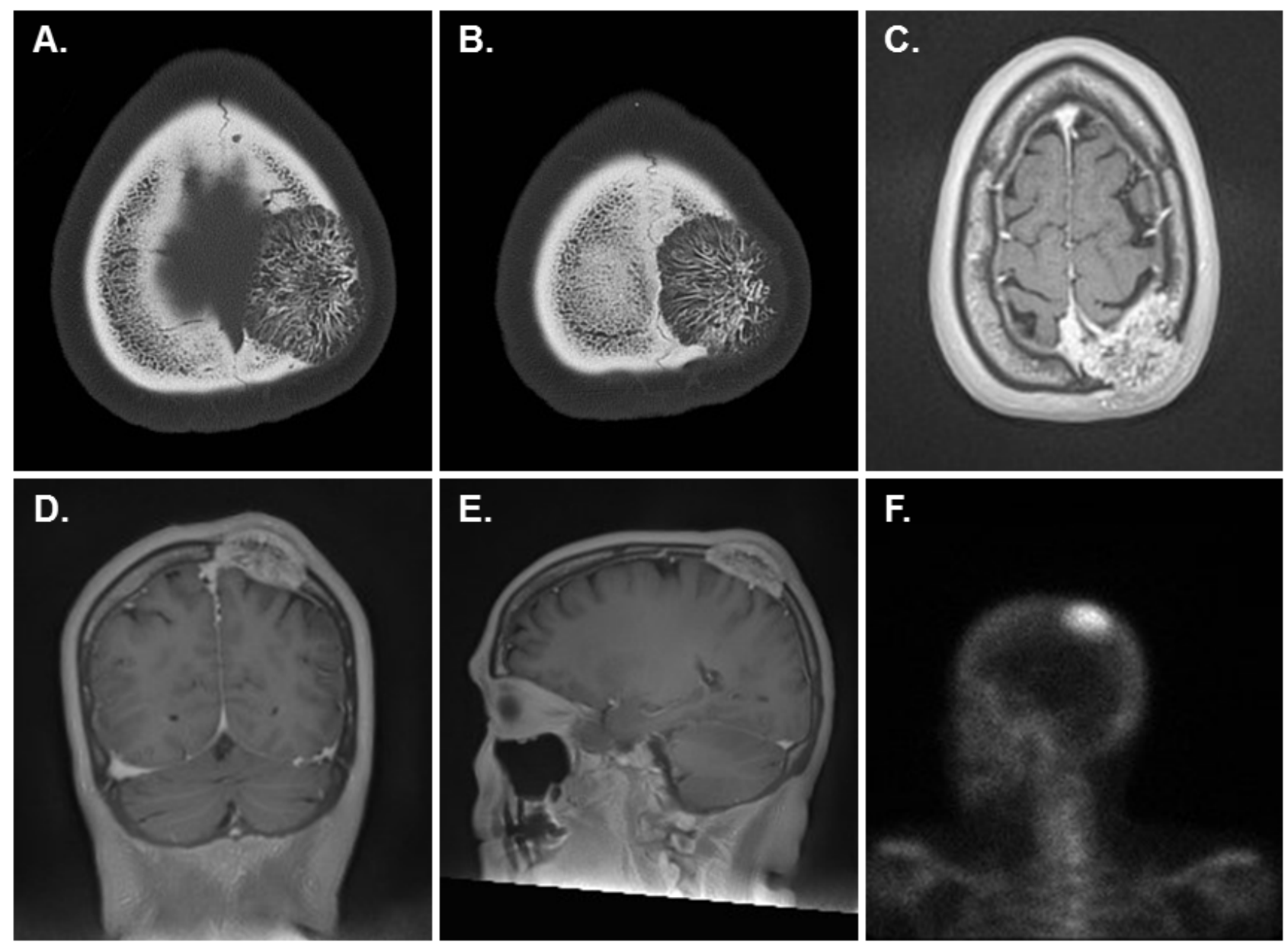

Figure 1: Radiographic images of the left frontoparietal mass. A,B) CT head without contrast revealed an expansile, spiculated osseous lesion in the left frontoparietal calvarium with a small soft tissue component along its superficial surface (A, B, Axial); C,D,E) T1-weighted MRI brain with and without contrast identified an expansile, striated, enhancing left frontoparietal bone lesion which indented the extra-axial space of the left parietal region with extension outside the cortex into the soft tissues (C, Axial; D, Coronal; E, Sagittal); F) Total body bone scan revealed a solitary lesion in the skull (left lateral view of the head is shown).
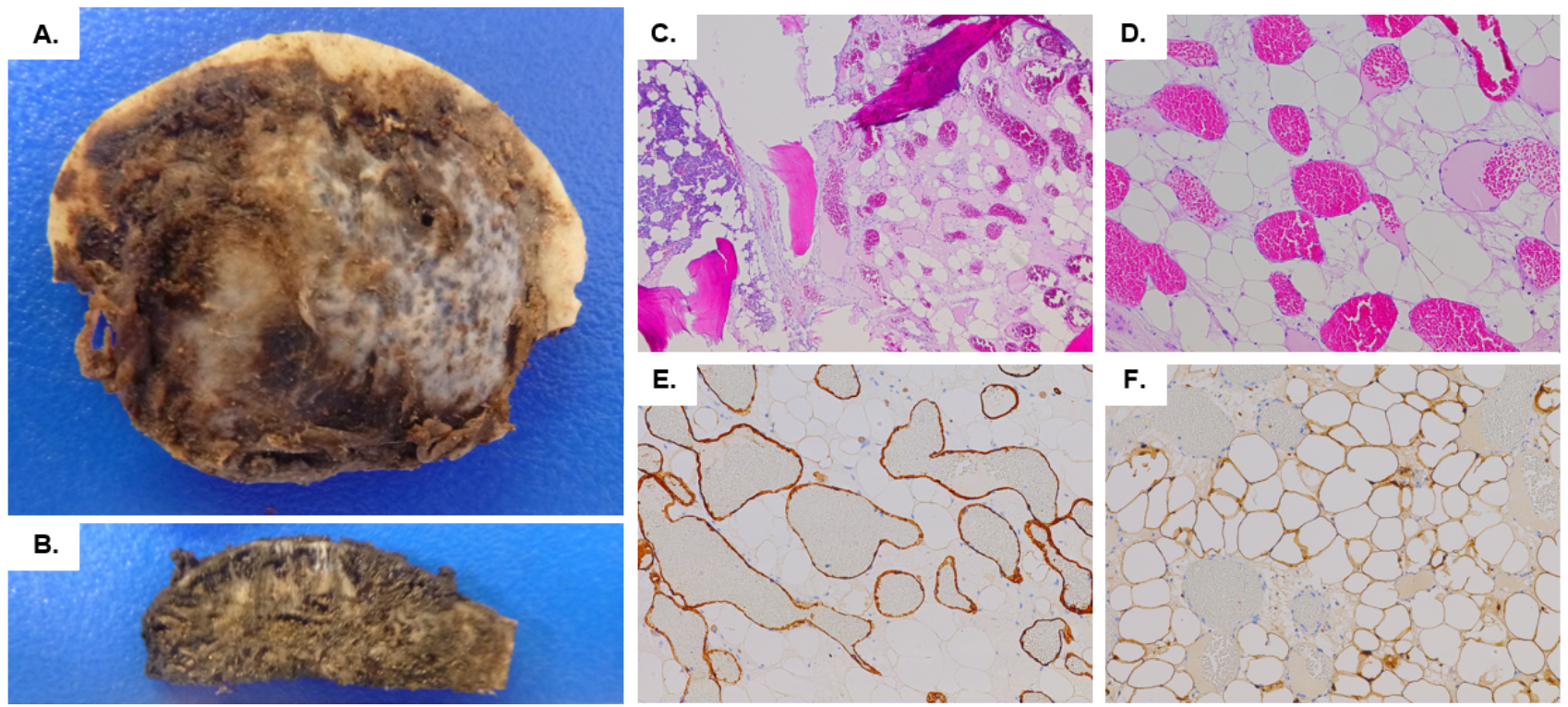

Figure 2: Resected left frontoparietal mass and microscopic findings. A) The specimen grossly consisted of an oval portion of cranium with a raised area on the convex surface; B) Upon sectioning, the cut surface revealed a dark red-gray appearance spanning the entire thickness of the bone and raised area; C, D) Histologically, the calvarial mass was composed of mature adipose tissue and disorganized thin-walled blood vessels (H\&E, C: 40X, D: 100X); E, F) The immunophenotype was positive for CD34 staining the vascular endothelium (E, 100x) and S100 highlighting the adipocytes (F, 100x). 
this solitary lesion in the skull (Figure 1F). Given the rapid growth and etiological uncertainty of the bone lesion, a left frontoparietal craniectomy for complete resection of the mass with subsequent cranioplasty was performed. The excised lesional skull bone was sent for histopathological examination. Clinical follow-up with the patient showed no recurrence of this tumor.

\section{Pathological examination}

The craniectomy specimen grossly consisted of an oval mass lesion measuring approximately $4.0 \times 3.0 \times$ $0.6 \mathrm{~cm}$ in overall dimensions with cranial convex surface on one side demonstrating diffuse pitting of the bone (Figure 2A). Upon sectioning, the cut surface revealed a dark red-grey appearance spanning the entire thickness of the bone, including the aforementioned raised area (Figure 2B). After formalin fixation, the sections were decalcified in Immunocal (100\% formic acid) for approximately two days. Representative sections were taken, including six full thickness sections from the contralesional portion of the bone. The tissue was then paraffin-embedded and 4- $\mu \mathrm{m}$ sections were obtained. The resulting sections were stained with hematoxylin and eosin (H\&E). Microscopic examination showed that the mass lesion was composed of mature adipose tissue admixed with disorganized thin-walled blood vessels. Cytological a typia, mitosis or necrosis was not identified (Figure 2C and Figure 2D). Immunohistochemical (IHC) studies demonstrated that the vascular endothelium expresses CD34 (Figure 2E) and the mature adipocytes express S100 (Figure 2F).

Based on the above findings, the diagnosis of cranial intraosseous angiolipoma was generated.

\section{Discussion}

Although intraosseous angiolipomas are seen at extra-cranial sites, cranial intraosseous angiolipoma is rarely encountered. Due to its non-specific clinical characteristics and presentation, histopathological evaluation plays an essential role in clinical management. Our literature search revealed only five reported cases of intraosseous angiolipoma involving the cranium, the salient clinic pathological features of which are summarized in Table 1 and discussed below.

Intraosseous angiolipomas are slow-growing and can

Table 1: Clinicopathological features of reported cases of cranial intraosseous angiolipoma.

\begin{tabular}{|c|c|c|c|c|c|c|c|}
\hline Reference & $\begin{array}{l}\text { Age } \\
\text { (years)/ } \\
\text { Gender }\end{array}$ & Location & $\begin{array}{l}\text { Period of } \\
\text { Expansion }\end{array}$ & $\begin{array}{l}\text { History } \\
\text { of Head } \\
\text { Trauma }\end{array}$ & $\begin{array}{l}\text { Clinical } \\
\text { Features/ } \\
\text { Neurological } \\
\text { Examination }\end{array}$ & $\begin{array}{l}\text { Radiographic } \\
\text { Findings }\end{array}$ & Histopathology ${ }^{*}$ \\
\hline $\begin{array}{l}\text { Amir } \\
\text { jamshidi, } \\
\text { et al. [10] }\end{array}$ & $\begin{array}{l}41 / \\
\text { Female }\end{array}$ & $\begin{array}{l}\text { Right } \\
\text { frontotemporo- } \\
\text { parietooccipital }\end{array}$ & 2 years & No & $\begin{array}{l}\text { Tender to } \\
\text { palpation, } \\
\text { Headache }\end{array}$ & $\begin{array}{l}\text { X-ray, CT, \& MRI: } \\
20 \mathrm{~cm} \text { expansile, } \\
\text { Non-enhancing } \\
\text { lesion extending } \\
\text { along the diploe } \\
\text { and destroying } \\
\text { the internal and } \\
\text { external tables } \\
\text { with cerebral } \\
\text { compression }\end{array}$ & $\begin{array}{l}\text {-Gross: Yellow } \\
\text { lipomatous bone } \\
\text { with cancellous and } \\
\text { vascular components; } \\
\text {-Histo: Some lesional } \\
\text { vessels with fibrin } \\
\text { thrombi, no cellular a } \\
\text { typia or mitotic figures; } \\
\text {-IHC: S100 neg, CD34 } \\
\text { pos, Sudan black pos }\end{array}$ \\
\hline $\begin{array}{l}\text { Atilgan, et } \\
\text { al. [7] }\end{array}$ & $\begin{array}{l}16 / \\
\text { Female }\end{array}$ & Right frontal & "long time" & No & $\begin{array}{l}\text { Swelling, } \\
\text { Headache }\end{array}$ & $\begin{array}{l}\text { CT: } 2 \mathrm{~cm} \text { well } \\
\text { defined lesion } \\
\text { with no bone } \\
\text { destruction or soft } \\
\text { tissue component }\end{array}$ & $\begin{array}{l}\text {-Gross: Yellow-brown } \\
\text { solid lesion; } \\
\text {-Histo: Some } \\
\text { lesional vessels with } \\
\text { neutrophils and fibrin } \\
\text { thrombi, no mitosis } \\
\text { or necrosis, Average } \\
\text { of } 10 \text { mast cells per } 1 \\
\text { HPF; } \\
\text {-IHC: CD34 pos, } \\
\text { CD31 pos, VEGF } \\
\text { pos, TGFbetapos, } \\
\text { TNFalphapos }\end{array}$ \\
\hline $\begin{array}{l}\text { Nguyen, } \\
\text { et al. [8] }\end{array}$ & 55/Male & Right frontal & - & - & $\begin{array}{l}\text { Headache, } \\
\text { Nausea, } \\
\text { Vomiting, } \\
\text { Diplopia, Facial } \\
\text { asymmetry } \\
\text { [concurrently } \\
\text { diagnosed } \\
\text { with metastatic } \\
\text { invasive } \\
\text { ductal breast } \\
\text { carcinoma] }\end{array}$ & $\begin{array}{l}\text { CT \& MRI: } 4.3 \mathrm{~cm} \\
\text { heterogeneously } \\
\text { enhancing lesion } \\
\text { with cerebral } \\
\text { compression, } \\
\text { But without } \\
\text { involvement of } \\
\text { overlying soft } \\
\text { tissue }\end{array}$ & $\begin{array}{l}\text {-Gross: Well } \\
\text { circumscribed, mixed } \\
\text { areas of firm-to-soft } \\
\text { tan and red lobulated } \\
\text { tissue; } \\
\text {-Histo: No cytologic } \\
\text { atypia or mitoses; } \\
\text {-IHC: Pankeratinneg }\end{array}$ \\
\hline
\end{tabular}




\begin{tabular}{|c|c|c|c|c|c|c|c|}
\hline $\begin{array}{l}\text { Singh, et } \\
\text { al. [6] }\end{array}$ & $\begin{array}{l}30 / \\
\text { Female }\end{array}$ & Right parietal & $\begin{array}{l}5 \text { years, } \\
\text { following } \\
\text { pregnancy }\end{array}$ & No & $\begin{array}{l}\text { Altered } \\
\text { sensation over } \\
\text { area without pain } \\
\text { on palpation }\end{array}$ & $\begin{array}{l}\text { CT \& MRI: } 6.4 \\
\text { cm mass with } \\
\text { expansion of } \\
\text { diploid space } \\
\text { and cerebral } \\
\text { compression }\end{array}$ & $\begin{array}{l}\text {-Histo: No cytologic } \\
\text { atypia; } \\
\text {-IHC: epithelial } \\
\text { membrane antigen neg }\end{array}$ \\
\hline $\begin{array}{l}\text { Yu, et al. } \\
{[9]}\end{array}$ & 50/Male & Right parietal & 11 years & $\begin{array}{l}\text { Minor } \\
\text { trauma }\end{array}$ & Swelling & $\begin{array}{l}\text { CT: } 7 \mathrm{~cm} \\
\text { spiculated, Non- } \\
\text { enhancing lesion } \\
\text { with cerebral } \\
\text { compression }\end{array}$ & $\begin{array}{l}\text {-Gross: Yellow-brown } \\
\text { lesion of variable } \\
\text { consistency; } \\
\text {-Histo: Well } \\
\text { circumscribed non } \\
\text { encapsulated lesion, } \\
\text { scattered mast cells, } \\
\text { no thrombi }\end{array}$ \\
\hline Our case & $\begin{array}{l}61 / \\
\text { Female }\end{array}$ & $\begin{array}{l}\text { Left } \\
\text { frontoparietal }\end{array}$ & 6 months & $\begin{array}{l}\text { Minor } \\
\text { trauma }\end{array}$ & Swelling & $\begin{array}{l}\text { Bone scan, } \\
\text { CT \& MRI: } 4.4 \\
\text { cm expansile, } \\
\text { Spiculated, } \\
\text { Enhancing lesion } \\
\text { with superficial } \\
\text { soft tissue } \\
\text { component } \\
\text { and cerebral } \\
\text { compression }\end{array}$ & $\begin{array}{l}\text {-Gross: Dark red-grey } \\
\text { cut surface; } \\
\text {-Histo: No cytologic } \\
\text { atypia or mitosis or } \\
\text { necrosis; } \\
\text {-IHC: CD34 pos, S100 } \\
\text { pos }\end{array}$ \\
\hline
\end{tabular}

"All specimens histologically demonstrated an admixture of mature adipose tissue and thin-walled blood vessels. (Histo: Histology; IHC: Immunohistochemistry; Neg: Negative; Pos: Positive; HPF: High power field).

take months to years to develop before coming to the attention of clinicians. Although our patient as well as one of the five literature-documented cases [9] had noted the enlarging skull mass following head trauma, whether there is an association between head trauma and cranial intraosseous angiolipomas remains unclear and requires further investigation. The clinical presentation of a cranial intraosseous angiolipoma varies depending on the location and size of the tumor. In the reported cases, the most common symptoms included headache and altered sensation or tenderness to palpation at the site of the mass $[6-8,10]$, while others, including our patient, were asymptomatic [9]. It is noted that the mass lesion involved the frontal and parietal area of the skull in all five previously reported cases as well as our case, which may suggest the site predilection of intraosseous angiolipomas.

Every documented case of cranial intraosseous angiolipoma underwent at least CT imaging to evaluate the lesion. Radiographically, the depiction of the expansile masses varied, utilizing such descriptors as trabeculated, lytic, or spiculated. Enhancement of the lesional parenchyma depends upon the extent of the vascular component, with only our case and another reported case [8] documenting contrast enhancement of the angiolipoma. The majority of the cases, including our own, had radiographic evidence of some degree of mass effect and cerebral compression from the tumor, but the lesion did not invade the brain parenchyma.

While the slow-growing nature of these lesions may allow clinicians to initially employ an observational management strategy [9], the lack of lesion-specific clinical characteristics and concern for a malignant process result in eventual surgical resection of these cranial masses. Histopathologically, every resected intraosseous angiolipoma demonstrated mature adipose tissue admixed with thin-walled blood vessels without significant cytologic a typia or mitosis. In some instances, mast cells $[7,9]$ and fibrin thrombi $[7,10]$ were noted. Immunohistochemical staining was utilized to confirm the histology noted on H\&E, including highlighting the vascular component with endothelial markers such as CD34 $[7,10]$ and the adipose component with adipocyte markers such as S100 (our case) or Sudan black [10]. In some cases, immunohistochemical studies were employed to rule out other possible diagnoses, such as intraosseous meningioma and carcinoma metastasis.

The prognosis for angiolipomas is excellent, with surgical excision being considered curative, along with a very low risk of local recurrence and no known risk of malignant transformation. The natural history of an intraosseous angiolipoma demonstrates that growth appears to be secondary to the vascular component, which is responsible for the progressive expansion of the bone [9]. The expansile nature of cranial intraosseous angiolipomas result in skull deformity and, depending on location, may be accompanied by neurological sequelae.

\section{Acknowledgements}

The authors thank Wendy Reed, PA (ASCP) for photographing and grossing the craniectomy surgical specimen.

\section{Conflict of Interest Statement}

The authors of this paper have no conflicts of interest to disclose. This paper was composed without funding from any institution. 


\section{References}

1. Lin JJ, Lin F (1974) Two entities in angiolipoma. A study of 459 cases of lipoma with review of literature on infiltrating angiolipoma. Cancer 34: 720-727.

2. Celik A, Sezen CB, Ertunc O, Tastepe Al (2015) Intraosseous angiolipoma of the rib. Indian J Surg 77: 1409-1410.

3. Hall FM, Cohen RB, Grumbach K (1986) Case report 377 : Intraosseous lipoma (angiolipoma) of right third rib. Skeletal Radiol 15: 401-403.

4. Manganaro AM, Hammond HL, Williams TP (1994) Intraosseous angiolipoma of the mandible: A case report and review of the literature. J Oral Maxillofac Surg 52: 767-769.

5. Hemavathy S, Roy S, Kiresur A (2012) Intraosseous angiolipoma of the mandible. J Oral Maxillofac Pathol 16: 283287.

6. Singh R, Josiah DT, Turner RC, David E Cantu-Durand, H James Williams, et al. (2016) Giant calvarial intraosseous angiolipoma: A case report and review of the literature. $\mathrm{J}$ Surg Case Rep.

7. Atilgan AO, Terzi A, Agildere $\mathrm{M}$, Caner $\mathrm{H}$, Ozdemir $\mathrm{BH}$ (2014) Intraosseous angiolipoma of the frontal bone with a unique location: A clinical and pathological case illustration and review of the literature. Indian J Pathol Microbiol 57: 301-304.

8. Nguyen L, Zwagerman NT, Grandhi R, McFadden K, Richardson RM (2014) Intraosseous Angiolipoma of the Cranium: Case report and review of the literature. Surg Neurol Int 5: 79.

9. Yu K, Van Dellen J, Idaewor P, Roncaroli F (2009) Intraosseous angiolipoma of the cranium: Case report. Neurosurgery 64: 189-190.

10. Amirjamshidi A, Ghasemi B, Abbasioun K (2014) Giant intradiploic angiolipoma of the skull. Report of the first case with MR and histopathological characteristics reported in the literature and a review. Surg Neurol Int 5: 50. 